\title{
Impacts of the Doha Round Framework Agreements on Dairy Policies
}

\author{
N. Suzuki ${ }^{1}$ and H. M. Kaiser ${ }^{2}$ \\ ${ }^{1}$ Department of Agricultural Economics, Kyushu University, Higashi-ku, Fukuoka 812-8581, Japan \\ ${ }^{2}$ Department of Applied Economics and Management, Cornell University, Ithaca, NY 14853-7801
}

\begin{abstract}
Dairy is highly regulated in many countries for several reasons. Perishability, seasonal imbalances, and inelastic supply and demand for milk can cause inherent market instability. Milk buyers typically have had more market power than dairy farmers. Comparative production advantages in some countries have led to regulations and policies to protect local dairy farmers by maintaining domestic prices higher than world prices. A worldwide consensus on reduction of border measures for protecting dairy products is unlikely, and dairy will probably be an exception in ongoing World Trade Organization (WTO) negotiations. Under the Doha Round framework agreements, countries may name some products such as dairy as "sensitive," thereby excluding them from further reforms. However, new Doha Round framework agreements depart from the current WTO rule and call for product-specific spending caps. Such caps will greatly affect the dairy sector because dairy accounts for much of the aggregate measure of support (AMS) in several countries, including the United States and Canada. Also, the amounts of dairy AMS in several countries may be recalculated relative to an international reference price. In addition, all export subsidies are targeted for elimination in the Doha Round, including export credit programs and state trading enterprises, which will limit options for disposing of surplus dairy products in foreign markets. Currently, with higher domestic prices, measures for cutting or disposing of surpluses have been used in many countries. Supply control, which is not regulated by WTO rules, remains as an option. Although explicit export subsidies are restricted by WTO rules, many countries use esoteric measures to promote dairy exports. If countries agree to eliminate "consumer financed" export subsidies using a theoretical definition and measurements proposed herein as Export Subsidy Equivalents (ESE), dairy exports in many countries may be affected. Although domestic supports and export subsidies will be reduced in the Doha Round, possi-
\end{abstract}

Received September 23, 2004.

Accepted January 26, 2005.

Corresponding author: H. M. Kaiser; e-mail: hmk2@cornell.edu. ble exclusion of "sensitive" products from tariff reduction will help some countries' dairy sectors survive after those final agreements. A key concern for those countries will be the simultaneous restriction of surplusdisposing measures. With fewer marketing options for surpluses, countries that continue border protection and high internal prices will likely be forced to use domestic supply control programs in the future.

(Key words: Doha Round, trade, policy)

Abbreviation key: AMS = aggregate measure of support; DPSP = Dairy Price Support Program; ESE = export subsidy equivalent; FMMO = Federal Milk Marketing Order; GP = guaranteed manufacturing milk price; JDC = Japan Dairy Council; MMB = Milk Marketing Board; SPP = standard purchase price; $\mathbf{S T E}=$ state trading enterprise; WTO = World Trade Organization.

\section{INTRODUCTION}

The dairy industry is one of the most regulated sectors in developed countries, with a whole host of economic regulations designed to protect dairy farmers, as evidenced by the high "Producer Subsidy Equivalents" and "Consumer Subsidy Equivalents" calculated by the organization for economic cooperation and development for dairy industries in most developed countries. It is reasonable to wonder whether dairy industries in those countries will survive in the more trade-liberalized world that will result when ongoing World Trade Organization (WTO) negotiations reach their new final agreements.

On July 31, 2004, an agreement on a framework for reducing agricultural supports was reached during the current round of the WTO negotiations (called the Doha Round), signaling that the general trend toward reducing dairy supports is inevitable. The accord states that all forms of export subsidies will be eliminated, although the timetable is left for future negotiations. "All forms of export subsidies" includes those generated by food aid, export credits, and exporting state trading enterprises (STE). The phrase "all forms of" is significant because it represents a departure from current WTO rules, which have no commitments to eliminate export subsidies and do not include food aid, export 
credits, and STE. The accord also classifies products based on tariff levels and mandates that higher tariffs be reduced more than lower ones. This, too, is a departure from the current WTO rules, which do not classify tariffs by level. Under the new agreement, however, each country can exclude some "sensitive" products from the reduction commitments to keep higher tariffs for them. With respect to domestic supports, the text calls for the most trade-distorting forms to be cut substantially, with product-specific capping of spending. This is yet another departure from current WTO rules, which use aggregate measure of support (AMS) for all items as the benchmark for reducing domestic supports.

The present paper discusses the possible implications of the Doha Round agreements on future dairy policies, taking into account the newly reached framework agreements. Before presenting this analysis, however, we first examine the causes for heavy governmental support of dairy industries in developed countries, focusing on the status of milk as a basic food (particularly for children), unique characteristics of milk, the oligopsonistic nature of milk markets, large differences in international competitiveness among countries, and political lobbying power of dairy interest groups. Our analysis of the implications of the Doha Round agreements highlights the dairy policies of the United States, Canada, and Japan, focusing on border measures (or import tariffs), domestic support programs, and surplus-eliminating measures (or supply control and export subsidies). Regarding export subsidies, it is argued that even New Zealand and Australia's dairy industries may be affected by regulation of "consumer financed" dairy export subsidies measured by an export subsidy equivalent (ESE) as defined in this paper.

\section{Why is Dairy so Heavily Protected?}

The most basic food. Milk is considered one of the most basic foods (especially for children) in many countries because it is a kind of perfect "all-in-one" food, with many major nutrients (Spencer and Blanford, 1977). Therefore, many countries have sought to promote an adequate supply of "wholesome" milk. Because many developed countries are currently facing over-supply problems rather than shortages, this goal is clearly more than being met. Now, suppose that, because of a free trade agreement, a significant portion of the domestic fluid milk supply were replaced by imports. The resulting low level of self-sufficiency in fluid milk might place in jeopardy the goal of maintaining dependable supplies of one of the most basic and important foods for the nation. Self-sufficiency, therefore, being the preferred means to maintaining dependable supplies, many governments have had to rely on protectionist and support policies to ensure sufficient domestic supplies of fluid milk.

Unique characteristics of milk. Milk, in its natural state, is bulky and highly perishable and must be quickly moved to the market for processing and distribution. Unlike most agricultural commodities, milk is produced daily, and adjustments in production in response to changes in input prices as well as milk prices take longer because of the high proportion of resources that are fixed over the short run. Thus, before the advent of policies and institutions designed to protect dairy farmers and before the development of technologies that made the shipment of milk over relatively long distances possible, the balance of market power rested with milk handlers (first buyers of milk), because individual dairy farmers had little choice other than to accept the handler's price or dump the milk.

To complicate matters, the milk industry sees a seasonal imbalance between milk demand and supply. In North American countries, milk production tends to be highest in the spring/summer months and lowest in the fall; fluid milk consumption is generally highest in the fall and lowest in the summer. In Japan, the opposite is true, i.e., milk supply is lowest in the summer, and demand is at its highest level. Perishability exacerbates this problem, because fluid milk cannot be stored during the high supply-low demand season for use later in the low supply-high demand months. Moreover, price elasticities of supply and demand for milk tend to be very inelastic, which means that even minor changes in supply or demand cause more severe changes in milk prices. These seasonal imbalances between supply and demand coupled with the very inelastic price elasticities of demand and supply cause significant seasonal variations in milk price and foster disorderly market conditions.

Government price support programs were introduced to even out seasonal imbalances by removing dairy products in the surplus season and selling them back to the market in the deficit season. These programs act similarly to buffer stock policies, which have the impact of stabilizing seasonal price swings. The basic mechanisms of dairy programs remain unchanged even today.

Oligopsonistic milk markets. Another justification for government intervention in milk markets is the oligopsonistic (i.e., many sellers relative to very few buyers of raw milk) structure of the market. Before the enactment of legislation designed to increase farmers' bargaining power and before modern transportation technologies designed to move milk greater distances, milk markets were highly localized, with farmers typically having few alternative buyers for their milk. Because of this, farmers were "price takers" (especially when there were market surpluses of raw milk, such 
as in the spring), having virtually no control over what price they received for their product. Furthermore, during times of surplus production, many farmers not only had to cope with low farm prices, but also had no outlets to sell their milk. Farmers who challenged handlers' price offers were often vulnerable to this situation; preventing it forms a basic rationale for the existence of federal and state milk marketing orders in the United States, which have strengthened the bargaining power of farmers and dairy cooperatives relative to milk handlers.

Today, the number of both farmers and milk handlers is drastically fewer than 75 yr ago. Government intervention is still justified by some on the grounds that milk markets continue to be oligopsonistic. However, a contrary argument is that with the tremendous consolidation and growth in dairy cooperatives, dairy farmers have more market power today relative to milk handlers than in the period when those programs began.

Large differences in international competitiveness. To keep domestic administrative prices sustainable, governments must implement some border measures-such as import quotas and tariffs-to prevent cheaper imports from flooding into the domestic market from abroad. Theoretically, total economic welfare is better served by making direct payments, compensating farmers for the gap between target and market prices without border measures, than by maintaining high domestic market prices with border measures. For dairy products, however, most countries (except New Zealand and Australia) have tariff-rate quotas with very high over-quota tariffs (most $>100 \%$ ), because direct payments to domestic dairy farmers have been considered to be too costly from a budget standpoint. An exception is Korea's tariff rate for dairy products, which is only $40 \%$.

The existence of high border protection in most countries is related to large differences in international competitiveness in dairy products. Producer milk prices in the US, Canada, and most European countries are almost twice the price in New Zealand (Shono and Kawaguchi, 1999). The producer milk price in Japan is almost 4 times the price in New Zealand. Dairy farming in Oceania is vastly different from what is found in other countries. Compared with domestic market-oriented operations in other countries based on both grain and pasture feeding, New Zealand and Australia's dairy farms are export-oriented, grazing-intensive operations based on huge pasturelands, and milk production costs are very low. Therefore, dairy farmers in most countries cannot compete with Oceanian farmers without border protection. This argument implies that dairy trade is based more on self-sufficiency instead of comparative advantage.
Political lobbying power. Many dairy farmers belong to cooperatives as a means to counter market power of dairy product processors and manufacturers. Dairy cooperatives perform many vital services to milk markets, including rationalizing the milk transportation system, balancing seasonal fluctuations, providing dependable supplies of raw milk to milk handlers, processing milk into fluid and manufactured products, and providing market information. These organizations also devote significant resources to lobbying governments for policies helpful to dairy farmers. Therefore, a greater proportion of farmers belong to cooperatives in the dairy industry than in other agricultural sectors in the US. In addition, cooperatives' power is reinforced by government regulations, because cooperatives have an important voice in shaping dairy legislation.

Furthermore, in some regions where the quality of land is marginal and not suitable for other forms of agriculture, dairy farming tends to be the only available enterprise for employment. Losing dairy farmers is equivalent to losing rural communities, and consequently, there is substantial political pressure to preserve dairies in those regions (e.g., Vermont in the United States and Hokkaido in Japan). An excellent example of legislation to preserve dairy farms was the Northeast Interstate Dairy Compact, which was passed because of considerable political power of both the dairy cooperatives in the region and the senior senator from Vermont. Interestingly, the Northeast Interstate Dairy Compact may have accelerated farm exits in the region because it enhanced asset values.

It is clear that the current state of significant government support for the dairy industry in many countries has powerful historical determinants, starting from the basic desire to ensure an adequate supply of a basic food. Less clear is what the fate of government dairy policies, and the industries themselves, will be under the new Doha agreements. It is to that question that we next turn.

\section{Implications of Doha Round Agreements for Future Dairy Policy}

Agreements on the framework to reduce agricultural supports in the Doha Round were reached on July 31, 2004. Whereas many of the actual details of the agreement still need to be negotiated by all countries, it is clear that the basic principle to reduce protection has been changed. The basic idea of the current (Uruguay Round) commitments is to apply the same percentage of reduction to all countries, but the Doha Round principle is to reduce greater percentages from countries and commodities with higher protection. Therefore, there will soon be pressure to reduce trade-dis- 
torting dairy supports. In the following sections, we discuss the possible impacts of the Doha Round agreements on dairy policies in the United States, Canada, and Japan. The focal topics are border measures (or import tariffs), domestic support programs, and surplus-eliminating measures (i.e., domestic supply control and export subsidies).

Can high border protection be maintained? The answer to this is probably "yes." The Uruguay Round requires reducing tariffs by $36 \%$, on average, and a minimum of $15 \%$ for all countries. Many countries applied the minimum 15\% reduction for dairy products with high tariffs. However, the new framework stipulates that products should be classified based on tariff levels and that higher tariffs should be reduced more than lower ones. This will be damaging to dairy products with high tariffs in many countries. However, the framework offers a compromise for countries to designate some products as sensitive, thereby exempting them from any further reforms. Many countries may choose to protect dairy products in this way.

Why did the WTO agree to exempt sensitive items? As mentioned previously, in many countries, milk is viewed as an essential food, and governments will want to assure adequate domestic supplies instead of relying on imports. In addition, dairy farmers in most countries have significant political power, and those in countries other than New Zealand and Australia may suffer from trade liberalization. There have been several empirical studies examining the impact of free trade arrangements on the US dairy industry. These studies have generally found that trade liberalization would not have a huge negative or positive impact on the United States dairy industry provided that trade liberalization is done multilaterally by all countries (Cox et al., 1999; de Gorter and Boughner, 1999; Larivière and Meilke, 1999; Shaw and Love, 2001; Nicholson, 2003). However, the extent of damage that farmers perceive they will suffer appears to exceed what current empirical evidence shows, and so it seems that it will be even more difficult to reach any worldwide consensus on substantial reduction of border measures for dairy. Consequently, there is a good possibility that dairy products will be treated as an exception in the ongoing trade negotiations.

Can domestic support programs be maintained? Border measures and domestic support programs are linked together. If border protection can be maintained, and it probably can, then domestic price support programs can be maintained. Although price support programs are not prohibited under the WTO rules, they have to be reduced because they are regulated by the AMS commitments. Because the current WTO rules use the total AMS as the benchmark for reducing domestic supports, reductions in dairy AMS could be avoided if other sectors' AMS amounts are adjusted to compensate for no reduction in dairy. However, the new Doha Round framework agreements will change this situation because the text calls for the most trade-distorting forms to be cut substantially, with product-specific capping of spending. When the product-specific spending cap is implemented, the dairy sector will be most significantly affected because it constitutes the major part of the AMS amounts in several countries, including the United States and Canada.

Another possibility that could affect dairy is a review of the AMS definition. However, how to include the gap between domestic and world prices for total milk production is ambiguous in calculating the AMS. There are difficulties in determining what constitutes the domestic administrative price and the international reference price.

For example, the United States government regulates milk prices mainly through the Dairy Price Support Program (DPSP) and Federal Milk Marketing Orders (FMMO). The 2002 Farm Bill introduced another nationwide support mechanism for fluid milk. The differences between the target and actual prices are paid by the government instead of by manufacturers or consumers. The direct unit payment is the difference between $\$ 16.94 / 100 \mathrm{lb}$ or $45.4 \mathrm{~kg}$ of milk and the FMMO Class I minimum price in Boston whenever the FMMO price is $<\$ 16.94$. To control government costs, the program has a maximum annual quantity limit for payments any farm can receive. In the United States, market prices of dairy products and manufacturing milk prices are supported by government purchases under the DPSP. The DPSP indirectly supports the farm milk price by the government's guarantee to buy manufactured dairy products at specified prices. Minimum prices handlers must pay for milk in alternative uses are set by FMMO. Based on the market prices of dairy products, the FMMO only sets minimum prices; the actual prices paid to farmers are usually above the minimums because of over-order premiums negotiated between dairy cooperatives and handlers. In this situation, the United States government now uses the difference between the DPSP support price $(\$ 9.90 / 100 \mathrm{lb}$ or $45.4 \mathrm{~kg}$ of milk) and the international reference price (about \$7.26) as a base for the AMS calculation, rather than the difference between the FMMO minimum (about $\$ 13$ to $\$ 14$ ) and the international reference price.

The Canadian government sets the purchase prices (called support prices) for butter and powder and, at the same time, calculates the corresponding manufacturing milk price manufacturers can pay to farmers. The provincial producers' Milk Marketing Board (MMB) and manufacturers have an agreement that the govern- 
ment-calculated raw milk price for butter and powder is used for their transaction. In addition, raw milk used in other dairy products (about 15 milk-utilization classes) is set in proportion to the government-calculated raw milk price for butter and powder. Roughly speaking, this implies that if the government-calculated price is raised by $3 \%$, all class prices for transactions between farmers and manufacturers are raised by $3 \%$. Because the supported purchase prices are almost the same as actual prices, manufacturers generally pay the corresponding raw milk prices and pass the cost along to retailers. There were direct payments for farmers until January 2002. The Canadian government gradually phased out this program, raising the government-supported purchase prices and the corresponding manufacturers' price for raw milk by the reduced amounts of the direct payments. Manufacturers transferred increases in their costs to retailers, and retailers raised retail prices of milk and dairy products. Therefore, abolishing the direct payments resulted in no decreases in farmers' revenues, and consumers paid more. What are administrative prices in Canada? The government does indeed calculate the supported purchase prices and the corresponding manufacturers' price for raw milk, but these are just "reference prices" for transactions between farmers' MMB and manufacturers. The government never forces farmers and manufacturers to use them; farmers and manufacturers "voluntarily" use the government-calculated prices as their transaction prices.

In addition, Canada (as well as other countries such as the United States) objects to the use of the current international reference price used to calculate the gap between domestic and world prices in the AMS. Western countries argue that because Oceanian dairy farming structure is so different from that in other countries, it is not appropriate to use Oceanian export prices as the international reference price to compare with domestic prices in other countries. Also, world prices are distorted from the use of export subsidies and, therefore, are not a good indicator of the true, non-distorted world price.

Unlike in the United States and Canada, there has not been a government purchase program for domestic dairy products in Japan since 1979. In addition, to reduce the AMS amounts quickly, all government-regulated prices were abolished in Japan in 2001, including: 1) the stabilization indicative price for major manufactured products, 2) the guaranteed manufacturing milk price (GP) for farmers, and 3) the standard purchase price (SPP) for manufacturers. (In Japan, price support programs were considered as measures prohibited by WTO rules, rather than as reduction-required measures.) The GP was calculated based on farmers' pro- duction costs, and the SPP was calculated as the manufacturers' payable price based on market prices of dairy products and the manufacturing allowance. Then, the difference between GP and SPP was paid to farmers as deficiency payments.

In Japan's new system, only the amount of the former deficiency payments, almost $10 \mathrm{yen} / \mathrm{kg}$, is maintained as a fixed payment. The fixed payment level is reviewed every year, taking into account the demand-supply situation and farmers' production costs. Currently, the market determines manufacturing milk prices. Regardless of the market price level, farmers receive the market price plus the fixed payment.

Another measure is a kind of revenue insurance program similar to one used in Canada. If the manufacturing milk market price is below the previous 3-yr average, farmers receive $80 \%$ of this difference from a fund created by the government and farmers themselves. Specifically, farmers are assessed 0.4 yen $/ \mathrm{kg}$ of manufacturing milk, and the government subsidizes this fund by 1.2 yen/kg of manufacturing milk.

Because Japan no longer uses administrative milk prices, the gap between domestic and world prices is not necessary to include the AMS in Japan, based on the current AMS definition. However, the possibility that the AMS definition may be reconsidered to avoid any inconsistency among countries in calculating the AMS under the Doha Round may affect dairy AMS amounts in many countries including the United States, Canada, and Japan.

How can milk surpluses be managed? If border measures and some domestic supports for dairy can be maintained even after the ongoing WTO negotiations produce agreements, domestic milk prices can be sustained above the market-clearing level. However, prices exceeding the market-clearing level will result in excess milk production unless supply-reducing policies are implemented. There are two major ways to avoid or manage surplus production: supply control and export subsidies.

Supply control. Supply control measures are not regulated by current WTO rules. In the United States, the support price for manufacturing milk has been gradually reduced over the past $15 \mathrm{yr}$, and the current level is rather low, as mentioned earlier. Because the market price is currently fluctuating above the support level, there are no significant milk surplus problems. Therefore, there are currently no government-sponsored supply control programs in the United States. In 2003, an industry-sponsored supply control program called the CWT (Cooperatives Working Together) program was initiated. The program was funded by a voluntary $\$ 0.05$ per cwt assessment on milk marketing, with the proceeds used to reduce milk supply. In the 
1980s, when the United States dairy industry experienced a chronic surplus of milk production, the government implemented 2 voluntary supply management programs to deal with this problem: the Milk Diversion Program in 1983 and the Dairy Termination Program in 1985. The basic feature of Milk Diversion Program was cash payments to farmers who signed a contract agreeing to market less milk between January 1, 1984 and March 31, 1985, than they did during a specified base period. Farms participating in the Dairy Termination Program were paid to slaughter or export their entire dairy herds. In addition, participants agreed to remove themselves and their facilities from dairy production for at least 5 yr (Suzuki and Kaiser, 1994).

Japan has a voluntary supply control program organized by the dairy farmers' central council [the Japan Dairy Council (JDC)]. However, for the past 5 yr, milk supply has not reached the upper limit of production quotas because of continuously declining milk production, which, in turn, was due to the government's gradual reduction in the guaranteed price for manufacturing milk (recall that the guaranteed price was eliminated in 2001).

In the late 1970s, Japan experienced a chronic milk surplus problem, and the government limited the quantity of milk eligible for the guaranteed price to lower deficiency payment costs. In response to the limited eligible quantity, the JDC imposed its own production quotas to avoid surplus production exceeding the limit. The Japanese supply control program is voluntary in that the cooperatives introduced it themselves; however, the program is mandatory in that rigid over-quota penalties are imposed on farms producing over-quota milk. For each farm in any given year, when production exceeds the quota, the subsequent year's quota is reduced by the amount of over-production. Mandatory production quotas have thus been imposed in Japan without legislation. This is primarily due to government action in 1966, in which only one cooperative in each prefecture was designated as the authorized organization to which the government makes deficiency payments. Consequently, farmers had to join the cooperative to receive the payments and, as a result, 95\% of all dairy farmers belong to these cooperatives. Thus, the JDC has the power to regulate the market milk supply. The JDC also has been making efforts to create some flexibility in the program by allocating more to those wishing to expand their quotas.

Canadian milk supply is probably the most strictly controlled in the world. The law prohibits any milk sales not going through each provincial MMB. Consequently, $100 \%$ of Canada's dairy farmers belong to a MMB. The federal and provincial governments set marketing quotas that limit sales of both manufacturing and fluid milk (Romain and Sumner, 2001), and the quotas are allocated to individual dairy farmers. Each farmer used to have separate fluid and manufacturing quotas, but currently they have a single quota for both. The quota is called "Market Sharing Quota" because the quota amounts are fixed not by quantity, but by market share of each farmer. Although the Canadian supply management system is not mandatory in that over-quota production is not prohibited, the strict penalties provide enough disincentive to over-produce that surpluses are not significant. Over-quota production receives very low prices (e.g., Can $\$ 19.23 / 100$ L compared to Can $\$ 63.15$ for fluid milk in Ontario on average in 2002 to 2003). Individual farmers' quotas are tradable within the province.

Export subsidies. Export subsidies are another key measure used to manage surpluses. The Doha Round framework agreements made a remarkable step in reducing export subsidies. Although food aid, export credits, and STE are not explicitly regulated under the current WTO rules, the Doha framework agreement states that all forms of export subsidies, including food aid, export credits, and STE, will be eliminated, although the timetable is left for future negotiations.

The Dairy Export Incentive Program in the United States and the European Union's export subsidies are now counted in the reduction commitments in the WTO, for they are explicit export subsidies from the government. The elimination commitment of direct export subsidies will affect European Union's dairy exports most significantly.

Because the agreement also says that indirect or hidden export subsidies, such as measures used by exporting STE, should be eliminated, a measure of those indirect export subsidies is necessary. That is, the mandate makes clear the need for a theoretical definition and practical measurements of hidden export subsidies unregulated under current WTO rules.

Figure 1 shows the difference between ordinary and hidden export subsidies. In the case of the ordinary export subsidies regulated in the current WTO rules, the producer price is the same as the consumer (or buyer) price, $\mathrm{P}_{\mathrm{d}}$, and the gap between domestic $\left(\mathrm{P}_{\mathrm{d}}\right)$ and lower export $\left(\mathrm{P}_{\mathrm{w}}\right)$ prices is paid by the government (or taxpayers) to exporters, as shown in Figure 1(a). On the other hand, STE may set a higher domestic price, $\mathrm{P}_{\mathrm{d}}$, and a lower export price, $\mathrm{P}_{\mathrm{w}}$, and pay producers the pooled price, $\mathrm{P}_{b}$, or the weighted average price from both sales, as shown in Figure 1(b). Under this scheme, consumers pay the entire amount of the subsidy, which is illustrated in Figure 1(b) by the black area being equal to the shadowed area. The only difference between ordinary and hidden export subsidies is that the former is paid by taxpayers, and the latter is financed 


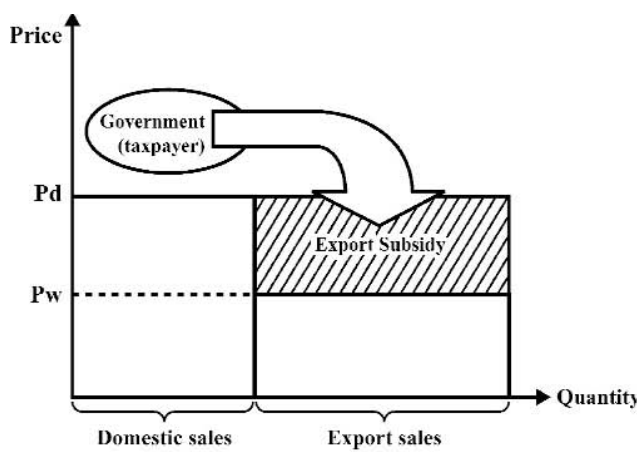

(a) Ordinary export subsidy regulated in the WTO

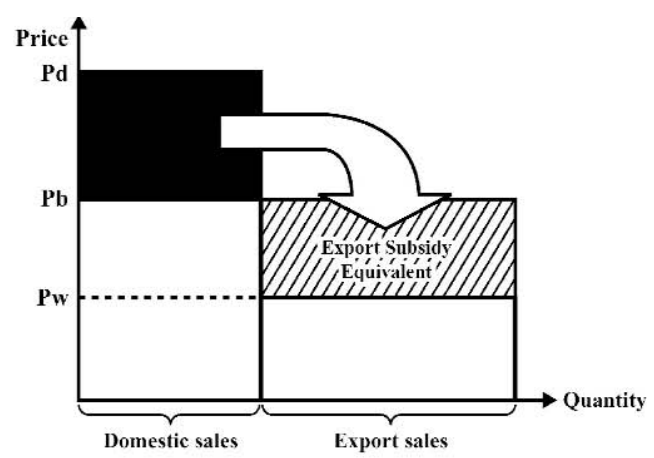

(b) Consumer financed hidden export subsidy

Figure 1. Ordinary and hidden export subsidies in the World Trade Organization (WTO). Pd $=$ domestic price, $\mathrm{Pw}=$ export price, and $\mathrm{Pb}=$ weighted average price from domestic and export sales. The ordinary export subsidy is paid by the government or taxpayers, as shown in (a). The hidden export subsidy is paid by consumers, as shown by the black area in (b).

by consumers. Therefore, the black or shadowed area in Figure 1(b) can be defined as a "consumer financed" ESE (Schluep, 1999). In this case, ESE can be calculated by the following formula:

$$
\mathrm{ESE}=\mathrm{Q}_{\mathrm{e}}\left(\mathrm{P}_{\mathrm{b}}-\mathrm{P}_{\mathrm{w}}\right)=\mathrm{Q}_{\mathrm{d}}\left(\mathrm{P}_{\mathrm{d}}-\mathrm{P}_{\mathrm{b}}\right)
$$

where $Q_{e}=$ export quantity, $Q_{d}=$ domestic sales quantity, $\mathrm{P}_{\mathrm{d}}=$ domestic price, $\mathrm{P}_{\mathrm{w}}=$ export price, and $\mathrm{P}_{\mathrm{b}}=$ pooled price.

Although Figure 1 explains ESE by price discrimination between domestic and export prices, it can also be easily extended to price discrimination among export markets. If the STE sets a higher price in foreign country 1 and a lower price in foreign country 2, consumers in foreign country 1 pay ESE instead of the domestic consumers. In the case of price discrimination between foreign markets 1 and 2, the definition of ESE can be expressed as:

$$
\mathrm{ESE}=\mathrm{Q}_{2}\left(\mathrm{P}_{\mathrm{b}}-\mathrm{P}_{2}\right)=\mathrm{Q}_{1}\left(\mathrm{P}_{1}-\mathrm{P}_{\mathrm{b}}\right)
$$

where $\mathrm{Q}_{1}=$ sales quantity in country $1, \mathrm{Q}_{2}=$ sales quantity in country $2, \mathrm{P}_{1}=$ price in country $1, \mathrm{P}_{2}=$ price in country 2 , and $\mathrm{P}_{\mathrm{b}}=$ pooled price.

It should be noted that the FMMO in the United States has characteristics similar to those described previously, because it uses price discrimination between fluid and manufacturing milk, with a blend (pooled) price paid to farmers. Restricting fluid sales through setting administratively higher prices for milk used in beverages results in lower manufacturing prices, which make surpluses easier to export whenever manufacturing market prices are above supported levels.

Therefore, we should recognize that the United States, Canada, Australia, and New Zealand each use programs to promote dairy exports. If member countries agree to reduce "consumer financed" export subsidies using a theoretical definition and practical measurements proposed here as ESE, dairy exports in many countries, including Australia and New Zealand, may be affected based on the commitment to the elimination of all forms of export subsidies.

There is one further point to make related to export subsidies. Under current WTO rules, the reduction commitments are more severe for export subsidies than for domestic policies. Although deficiency payments, in some cases, are actually export subsidies rather than domestic supports, lower reduction rates were applied by classifying them as domestic supports. To avoid this practice in the future, a clear definition is needed to determine whether a particular policy should be classified as an export subsidy or a domestic support policy. The Doha Round framework agreements state that the most trade-distorting domestic supports should be cut substantially. This may provide a way to reduce the imbalance of reduction rates caused by classification between domestic and export subsidies.

\section{CONCLUSIONS}

The dairy sector has been one of the most regulated sectors in many countries for various reasons. First, milk has historically been considered to be a basic food product, especially for children. Second, milk is a unique product because of its continuous production, high degree of perishability, seasonal imbalances between supply and demand, and supply and demand being highly price inelastic; those characteristics cause inherent instability in the market in terms of temporal price variability and market power. Third, milk markets have traditionally been local and oligopsonistic in nature, giving milk buyers a lot more market power 
than dairy farmers. Fourth, there are very large differences in comparative advantage in dairy production between Oceania and other regions, and border measures have been imposed to maintain high domestic prices relative to world prices. Finally, dairy cooperatives have been extremely effective in crafting regulations and policies to protect domestic dairy farmers. Therefore, it may be difficult to reach any worldwide consensus on substantial reduction of border measures for dairy products. Consequently, there is a good possibility that dairy will be treated as an exception in ongoing WTO negotiations.

This situation seems plausible under the Doha Round framework agreements. Under the accord, products will be classified based on tariff levels and higher tariffs must be reduced more than lower ones. However, countries may name some products as "sensitive," which would exclude them from any further reforms. Countries may choose to exclude dairy products using this provision.

However, the new Doha Round framework agreements call for the most trade-distorting forms to be cut substantially, with product-specific capping of spending. This is a departure from current the WTO rule, which uses the total AMS as the benchmark for reducing domestic supports. Some countries currently have active dairy price support programs. When the product-specific spending cap is implemented, the dairy sector will be the most significantly impacted because it accounts for a substantial part of the AMS amounts in several countries, including the United States and Canada. Also, there is a possibility that the dairy AMS amounts in several countries may be recalculated through detailed reviews of the definition of the domestic administrative price and the international reference price.

In addition, all forms of export subsidies are targeted for elimination, including export credit programs and STE in the Doha Round. This will limit opportunities to dispose of surplus dairy products in foreign markets. Currently, with higher domestic prices, measures for cutting or disposing of surpluses have been implemented in many countries. Supply control, which is not regulated by WTO rules, can be used in the future. Although explicit export subsidies are restricted by WTO rules, many countries have been using esoteric dairy export promoting measures. If member countries agree to eliminate "consumer financed" export subsidies using a theoretical definition and practical measurements proposed here as ESE, dairy exports in many countries including Australia and New Zealand may be affected.

Although domestic support programs and export subsidies will be reduced more significantly in the Doha Round than in the Uruguay Round, possible exclusion of "sensitive" products from tariff reduction commitments will help some countries' dairy sectors survive a more trade-liberalized world after the Doha Round reaches final agreements. A key concern for those countries will be the simultaneous restriction of surplus-disposing measures under the Doha Round. With less ability to dump surpluses in foreign markets, countries that continue border protection and high internal prices will be forced to rely on domestic supply control programs in the future.

\section{REFERENCES}

Cox, T., J. R. Coleman, J.-P. Chavas, and Y. Zhu. 1999. An economic analysis of the effects on the world dairy sector of extending Uruguay Round Agreement to 2005. Can. J. Agric. Econ. 47:169-183.

de Gorter, H., and D. S. Boughner. 1999. U.S. dairy policy and agreement on agriculture in the WTO. Can. J. Agric. Econ. 47:31-42.

Larivière, S., and K. Meilke. 1999. An assessment of partial dairy trade liberalization on the US, EU-15, and Canada. Can. J. Agric. Econ. 47:59-73.

Nicholson, C. F. 2003. Trade Liberalization and the U.S. Dairy Industry. Weblet, Dep. Appl. Econ. Manage., Cornell Univ., Ithaca, NY.

Romain, R. F., and D. A. Sumner. 2001. Dairy economic and policy issues between Canada and the United States, Can. J. Agric. Econ. 49:479-492.

Schluep, I. 1999. The law and economics of "consumer only" financed export subsidies: A context for the WTO panel on Canadian dairy pricing policy, MS Thesis, Cornell Univ., Ithaca, NY.

Shaw, I., and G. Love. 2001. Impacts of Liberalizing World Trade in Dairy Products. Australian Bureau of Agricultural and Resource Economics, Canberra, Australia. ABARE Research Report 01.4.

Shono, C., and T. Kawaguchi. 1999. Studies on spatial equilibrium model of international trade under tariff quota system with specific and ad valorem duties: The case of oligopolistic international trade, Sci. Bull. Fac. Agric., Kyushu Univ. 54(1-2):85-96 (in Japanese).

Spencer, L., and C. J. Blanford. 1977. An Economic History of Milk Marketing and Pricing: 1800-1933, Volume 1, Grid Inc., Columbus, $\mathrm{OH}$.

Suzuki, N., and H. M. Kaiser. 1994. Basic mechanisms of Japanese dairy policy and milk market models: A comparison with US dairy policy. J. Dairy Sci. 77:1746-1754. 